\title{
Study on Serially Connected PV Modules under Partial Shading Condition
}

\author{
Byunggyu Yü ${ }^{1}$, Seok-Cheol Ko ${ }^{2}$ \\ ${ }^{1}$ Division of Electrical, Electronic and Control Engineering, Kongju National University, Republic of Korea. \\ ${ }^{2}$ Industry-University Cooperation Foundation, Kongju National University, Republic of Korea. \\ ${ }^{1}$ ORCID: 0000-0001-5648-4268
}

\begin{abstract}
Recently, photovoltaic (PV) generation has been widely installed around the world, because it can be used to solve fossil-fuel shortage crisis and avoid the environmental crisis caused by fossil-fuels. For a residential PV application, the serial connected PV modules are normally designed for matching with the corresponding PV inverter specification. In this paper, the study on a serially connected PV modules characteristics under partial shading condition. For verifying the analysis method, three commercial PV modules are considered by using PSIM simulation under varying irradiance condition, which means under shading condition. As a result, the distorted characteristics of PV array can be easily developed under shading conditions by using the proposed analysis method. The proposed simulation modeling could be used in the application of PV system performance analysis, especially for maximum power pointing tracking (MPPT) performance.
\end{abstract}

Keywords: PV generation, PV modules, PV characteristics, Shading condition.

\section{INTRODUCTION}

$\mathrm{PV}$ generation is the conversion of sunlight into an electricity using solar cell that exhibit PV effect. As one of the prominent renewable energy sources, PV has been widely industrialized and studied around the world, since renewable energy has been regarded to solve the environmental problem caused by fossil fuel as a new industry and also has large availability in the Earth's crust [1-3].

As shown in Figure 1, residential PV application are becoming more popular with mass adoption because of gradual cost reduction along with continuous technical advancements [4-6]. Residential PV systems, averaging around 5 kilowatts (kW), are typically smaller than commercial PV systems, averaging closer to $200 \mathrm{~kW}$ [7].

The open circuit voltage of most crystalline silicon PV modules is around 40 volts and the configuration of PV modules are determined by the corresponding PV inverter. Especially for residential PV application, PV modules are connected serially and for most string inverter, the voltage window is between 300 to 500 volts. This would mean that the number of serially connected PV modules is between 8 and 12 panels. This creates a string circuit and the wiring running from the PV module's negative terminal is connected to the next PV module's positive terminal and so forth down the string line.
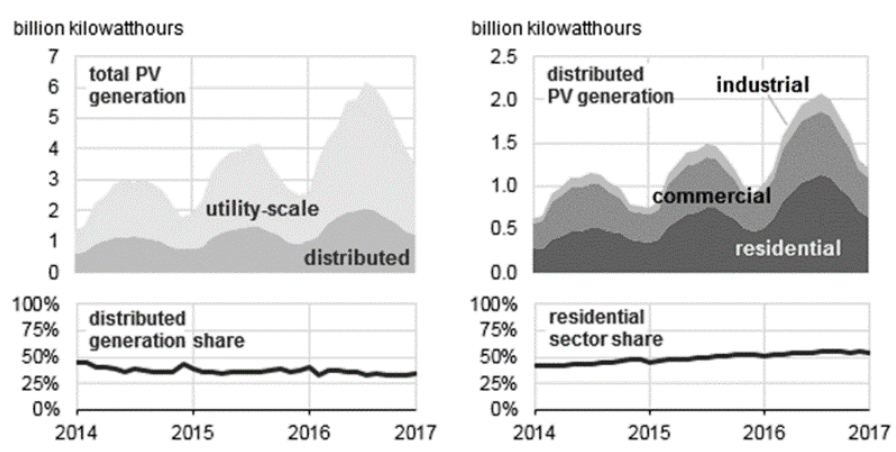

Figure 1. U.S. electricity generation from solar PV systems, according to U.S. Energy Information Administration, Electric Power Monthly.

In the string PV configuration for the residential application, there is a critical issue under shading condition. Specifically, the total power is degraded by PV module under shading because PV modules are connected in series. Until now, the study on PV module characteristics under the shading condition has been conducted little, but the study on the generated power output by MPPT function in PV inverter has mainly carried out. Thus, this paper presents the study on a serially connected PV modules characteristics under partial shading condition, based on PSIM software analysis.

In this paper, a basic modeling of PV module is firstly introduced. Then, the simulation modeling and its results are presented under shading condition.

\section{MODELING OF PV MODULE}

The modeling of PV modules has been researched widely until now [8-12]. The series resistance $R_{s}$ of PV modeling was included, but not the parallel resistance for a moderate complexity [13], as shown in Fig. 2 (a). The same assumption is adopted by considering the shunt resistance $R_{s h}$ very large [14], as shown Fig. 2(b). In this paper, the series and parallel resistances are adopted for more higher accuracy [15], as shown in Fig. 2(c). 
International Journal of Engineering Research and Technology. ISSN 0974-3154, Volume 13, Number 1 (2020), pp. 54-57

(C) International Research Publication House. https://dx.doi.org/10.37624/IJERT/13.1.2020.54-57

By applying Kirchhoff's current law, current can be obtained by the equation:

$$
\begin{aligned}
& I_{p v}=I_{p h}-I_{d}-I_{s h} \\
& I_{p v}=I_{p h}-I_{o}\left(e^{\frac{q\left(V_{p v}+I_{p v} R_{S}\right)}{n k T}}-1\right)-\frac{\left(V_{p v}+I_{p v} R_{S}\right)}{R_{S h}}
\end{aligned}
$$

$G$ is irradiance, $I_{p v}$ is $\mathrm{PV}$ module output current, $V_{p v}$ is $\mathrm{PV}$ module output voltage, $I_{p h}$ is photo generated current, $R_{s}$ is module series resistance, $R_{s h}$ is module shunt resistance, $I_{d}$ is diode current, $k$ is Boltzmann's constant, $1.380658^{*} 10^{-23}[\mathrm{~J} / \mathrm{K}]$, $T$ is absolute temperature, $q$ is electronic charge $1.60 * 10^{-19}[\mathrm{C}]$, $n$ is diode quality factor, $I_{0}$ is diode saturation current.

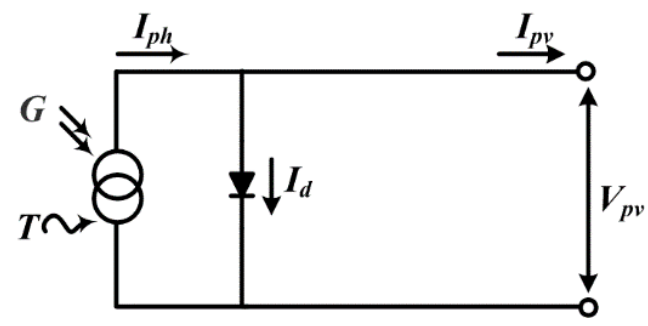

(a)

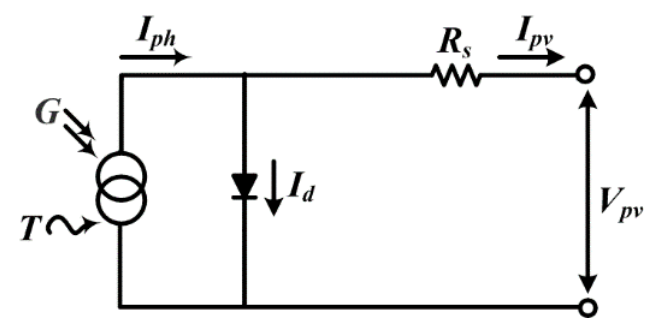

(b)

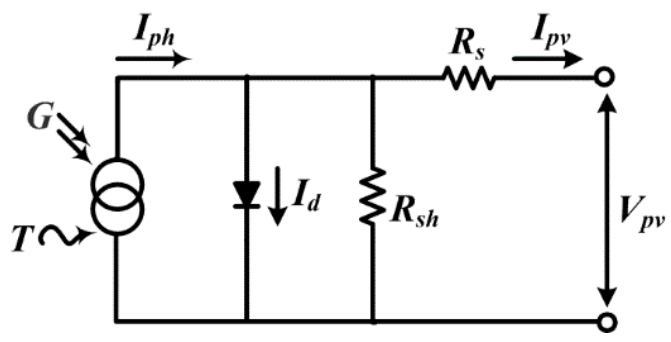

(c)

Figure 2. The equivalent circuit of PV module. (a) Ideal single diode model, (b) Practical model with $R_{s}$, (c) Practical model with $R_{s}$ and $R_{s h}$.

This paper is based on the most accurate model of PV model in (2) and focuses on the serially connected PV modules under shading condition in PSIM simulation. For practical considerations, specification of a commercial PV module for a PV string simulation is chosen as shown in Table 1 and the corresponding PV module characteristics are developed as shown in Fig. 3.
Table 1: Specification of a commercial PV module for a PV string simulation

\begin{tabular}{|c|c|c|c|}
\hline Parameter & Value & Parameter & Value \\
\hline$P_{\max }$ & $360[\mathrm{~W}]$ & $I_{s c}$ & $9.72[\mathrm{~A}]$ \\
\hline$V_{m p}$ & $38[\mathrm{~V}]$ & $\begin{array}{c}\text { Temperature } \\
\text { coefficient of } V_{o c}\end{array}$ & $-0.282\left[\% /{ }^{\circ} \mathrm{C}\right]$ \\
\hline$I_{m p}$ & $9.47[\mathrm{~A}]$ & $\begin{array}{c}\text { Temperature } \\
\text { coefficient of } I_{s c}\end{array}$ & $0.046\left[\% /{ }^{\circ} \mathrm{C}\right]$ \\
\hline$V_{o c}$ & $47.0[\mathrm{~V}]$ & $\begin{array}{c}\text { Temperature } \\
\text { coefficient of } P_{\max }\end{array}$ & $-0.394\left[\% /{ }^{\circ} \mathrm{C}\right]$ \\
\hline
\end{tabular}

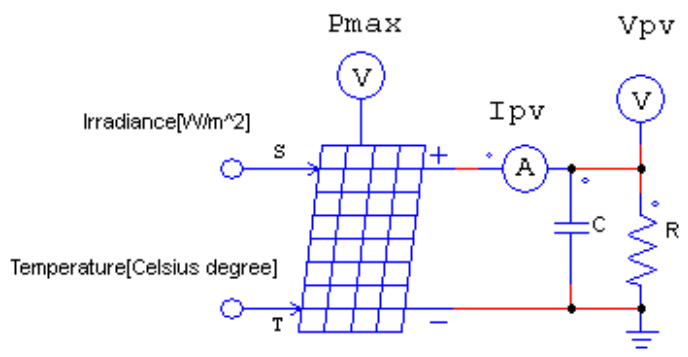

(a)

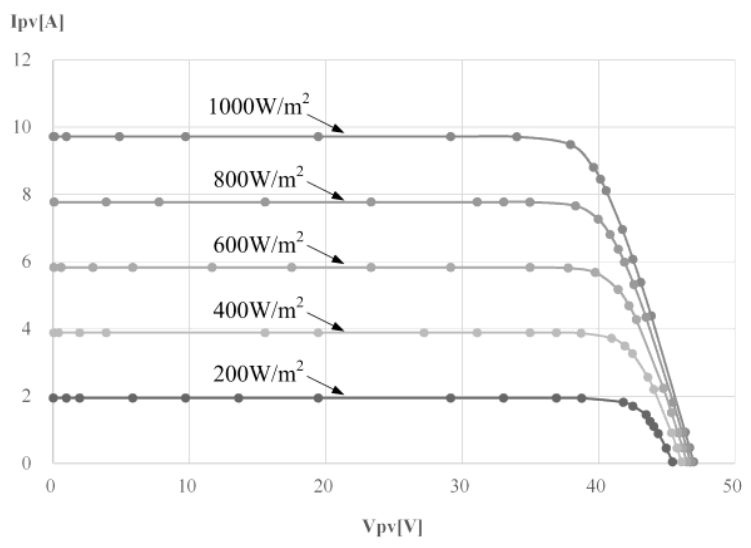

(b)

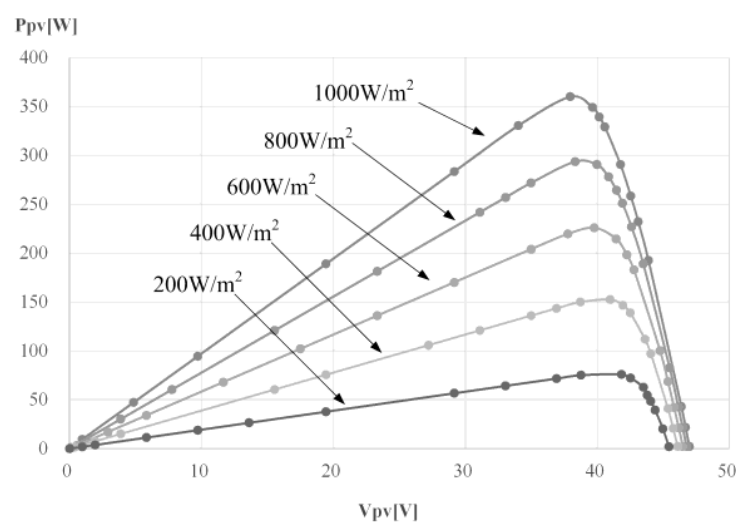

(c)

Figure 3. Simulated PV modeling using a commercial PV module specification. (a) Simulation circuit, (b) Voltagecurrent characteristics under varying irradiances, (c) Voltagepower characteristics under varying irradiances 
International Journal of Engineering Research and Technology. ISSN 0974-3154, Volume 13, Number 1 (2020), pp. 54-57

(C) International Research Publication House. https://dx.doi.org/10.37624/IJERT/13.1.2020.54-57

\section{SIMULATION RESULTS UNDER SHADING CONDITIONS}

Based on the previous simulation model, three different PV module connections in series are considered, as single module, two modules, three modules in series.

As shown in Fig. 4, the environmental condition is tested under standard test condition, which is $1000\left[\mathrm{~W} / \mathrm{m}^{2}\right]$, airmass 1.5 , and $25\left[{ }^{\circ} \mathrm{C}\right]$. In other word, shading condition is not considered to test the normal performance.

As shown in Figure 4 (a), the string current has the same short circuit current as $9.720[\mathrm{~A}]$ and the voltage is increased by the number of series connection. For a single module, the open circuit voltage is $46.970[\mathrm{~V}]$ and voltage/current at maximum power is 37.944[V] and 9.486[V], respectively. For two and three modules connection, open circuit voltage is $93.870[\mathrm{~V}]$ and $140.708[\mathrm{~V}]$, respectively. Accordingly, maximum power is increased by the number of series connection, in the same way, as shown in Fig. 4(b).

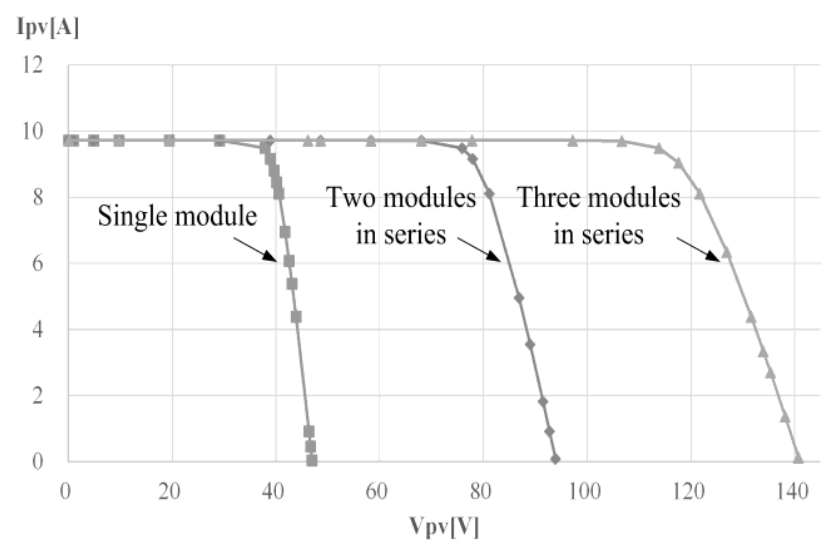

(a)

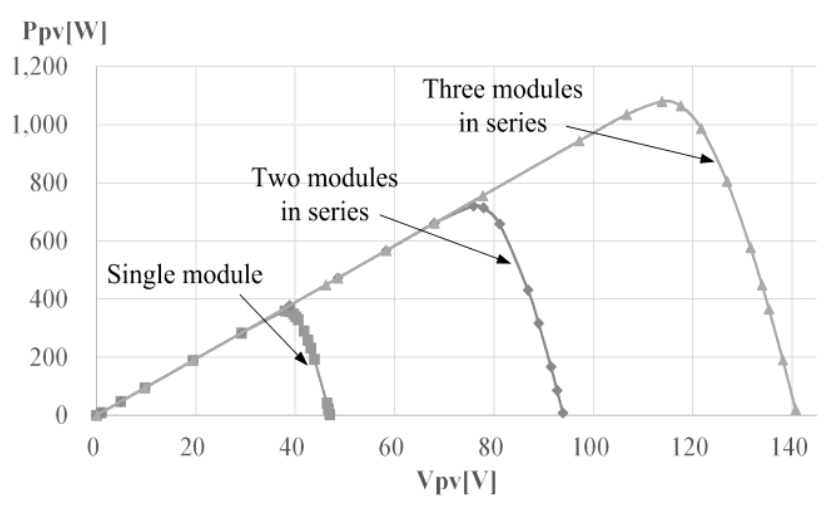

(b)

Figure 4. Simulation of a string PV modules without shading condition. (a) Voltage-current characteristics of three different PV module connections, (b) Voltage-power characteristics of three different PV module connections.
Table 2: Simulation scenarios for shading condition

\begin{tabular}{|l|l|l|}
\hline Scenario & Shading condition & Bypass diode \\
\hline Case 1 & No shading & Not attached \\
\hline Case 2 & Only one of three PV modules & Not attached \\
hase $30 \%$ shading. & Attached \\
\hline
\end{tabular}

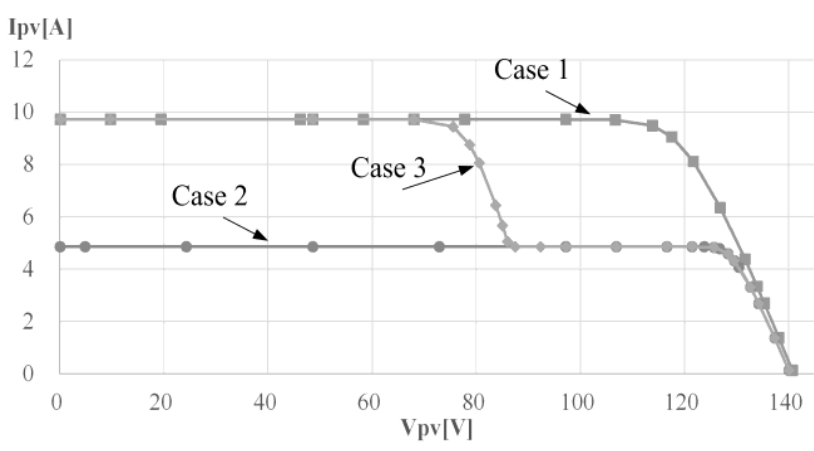

(a)

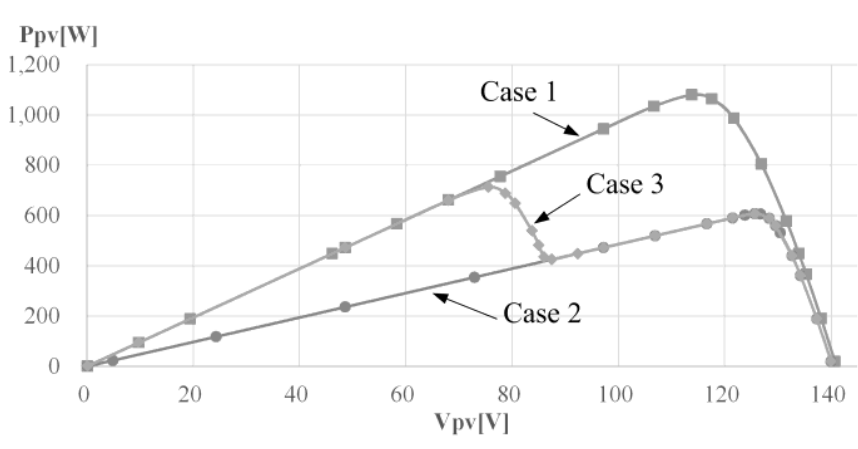

(b)

Figure 5. Simulation of a string PV modules without shading condition. (a) Voltage-current characteristics of three PV module connections in series, (b) Voltage-power characteristics of three PV module connections in series.

In order to verify the performance of PSIM simulation model, three different scenarios for shading are considered as Table 2, based on three PV modules string connection. For Case 1, three PV modules has the same performance just like Fig. 4. For Case 2, the short circuit current is dramatically decreased from 9.72[A] in Case 1 to 4.861[A], because the shaded PV module affects to the other two PV module power degradation by being connected in series. Thus, the maximum power for Case 2 is also decrease from 1080[W] for Case 1 to 607[W]. However, for Case 3, the shading effect can be less since the bypass diode is attached to the shaded PV module and the unshaded PV current has an alternative path to flow. Thus, for Case 3, there are two local maximum power points (MPP) which are 713[W] and 607[W]. Thus, it is concluded that power can be less generated and hot spot of PV module can be generated when bypass diodes are not installed. This paper focuses on the simulated PV modules in series under shading condition and more extended research on the analysis of hot spot and different local MPP will be discussed in the future research. 


\section{CONCLUSION}

This paper presents the study on a serially connected PV modules characteristics under partial shading condition. For verifying the analysis method, three commercial PV modules are considered by using PSIM simulation under shading condition. As a result, the distorted characteristics of PV array can be easily developed under shading conditions by using the proposed analysis method. The proposed simulation modeling could be used in the application of PV system performance analysis, especially for maximum power pointing tracking (MPPT) performance.

\section{ACKNOWLEDGEMENTS}

This work was supported by the research grant of the Kongju National University in 2019.

\section{REFERENCES}

[1] S. Eftekharnejad, G. T. Heydt, and V. Vittal, Optimal generation dispatch with high penetration of photovoltaic generation, IEEE Transaction on Sustainable energy, 6(3), 2015, 1013-1020.

[2] R. Wai and W. Wang, Grid-connected photovoltaic generation system, IEEE Transaction on Circuits and System 1, 55(3), 2008, 953-964.

[3] F. Blaabjerg, R. Teodorescu, M. Liserre, and A. V. Timbus, Overview of control and grid synchronization of distributed power generation systems, IEEE Transactions on Industrial Electronics, 53(5), 2006, 1398-1409.

[4] M. Khan, G. Norris, R. Chattopadhyay, I. Husain, and S. Bhattacharya, Autoinspection and permitting with a PV utility interface for residential plug-and-play solar photovoltaic unit, IEEE Transactions on Industry Applications, 53(2), 2017, 1337-1346.

[5] Y. Fujimoto, H. Kikusato, S. Yshizawa, S. Kawano, A. Yoshida, S. Wakao, N. Murata, Y. Amano, S. Tanabe, and Y. Hayashi, Distributed energy management for comprehensive utilization of residential photovoltaic outputs, IEEE Transactions on Smart Grid, 9(2), 12161227,2018 .

[6] S. Martin, J. Perez-Ruiz, and P. Lopez-Perez, Model to evaluate the system-wide impact of residential and commercial photovoltaic and storage units intended for self-consumption, IET Renewable Power Generation, 2111-2122, 2019.

[7] D. Chung, C. Davidson, R. Ru, K. Ardani, and R. Margolis, U.S. Photovoltaic prices and cost breakdowns: Q1 2015 benchmarks for residential, commercial, and utility-scale systems, NREL Technical Report -64746, 2015.

[8] M. Baig, H. Khan, and S. Ahsan, Evaluation of solar module equivalent models under real operating conditions- a review, Journal of Renewable and Sustainable Energy, 12, Published Online, 2020.
[9] D. Rusirawan and I. Farkas, Identification of model parameters of the photovoltaic solar cells, Energy Procedia, 57, 39-46, 2014.

[10] Y. Mahmoud and E. El-Saadany, Accuracy improvement of the ideal PV model, IEEE Transactions on Sustainable Energy, 6(3), 909-911, 2015.

[11] B. Babu and S. Gurjar, A novel simplified two-diode model of photovoltaic (PV) module, IEEE Journal of Photovoltaics, 4(4), 1156-1161, 2014.

[12] A. Souza, F. Melo, T. Oliveira, and C. Tavares, Performance analysis of the computational implementation of a simplified PV model and MPPT algorithm, IEEE Latin America Transactions, 14(2), 792798, 2016.

[13] G. Ciulla, V. Brano, V. dio, and G. Cipriani, A comparison of different one-diode models for the representation of I-V characteristic of a PV cell, Renewable and Sustainable Energy Reviews, 32, 684-696, 2014.

[14] R. Chenni, M. Makhlouf, T. Kerbache, and A. Bouzid, A detailed modeling method for photovoltaic cells, Energy, 32(9), 1724-1730, 2007

[15] K. Ishaque, Z. Salam, and Syafaruddin, A comprehensive MATLAB Simulink PV system simulator with partial shading capability based on two-diode model, Solar Energy, 85(9), 2217-2227, 2011. 